\title{
The effect of a chemically defined diet on the faecal flora and faecal steroid concentration
}

\author{
J. S. CROWTHER, B. S. DRASAR, P. GODDARD, M. J. HILL, AND \\ K. JOHNSON
}

From the Department of Bacteriology, St Mary's Hospital Medical School, London

SUMMARY The consumption of a chemically defined diet altered both the faecal flora and faecal steroids. Enterobacteria increased while enterococci and other lactic acid bacteria decreased in number. No other obvious change occurred. However, the alteration in the degree of degradation of the faecal neutral steroids may reflect some alteration in the anaerobic flora. Total excretion of both acid and neutral steroids was also reduced. On cessation of the diet both faecal flora and faecal steroids reverted to levels before the diet.

Water-soluble, chemically defined diets provide an ideal means of administering caloric-controlled diets (Winitz, Graff, Gallagher, Narkin, and Seedman, 1965) and have been used extensively in the treatment of obesity. Such diets might be expected to have a profound effect on the intestinal bacterial flora since all of the components should be fully absorbed from the small intestine and no dietary material should reach the colon to sustain the bacteria.

We are investigating the effects of various diets on the faecal bacterial flora and the faecal steroids (Aries, Crowther, Drasar, Hill, and Ellis, 1971; Hill, 1971) as part of a wider study of the aetiology of cancer of the colon (Hill, Crowther, Drasar, Hawksworth, Aries, and Williams, 1971) and of the breast (Hill, Goddard, and Williams, 1971). We have shown that people living for a time on diets normal except for a low fat content show a decline in faecal concentrations of bile acids and neutral steroids.

In this paper we report a study of the effect of a liquid diet containing no fibre and virtually no fat on the bacterial flora and the steroid composition of the faeces.

\section{Materials and Methods}

PERSONS STUDIED AND THEIR DIET

Three healthy male medical students consumed a liquid diet (produced by the Vivonex Corporation, Mountain View, California) for 10 days. The diet

Received for publication 3 July 1973. was supplied as a powder and is made up in tap water and consumed ad libitum. No other foods, except water, were allowed. Faecal samples were collected from each person during the dietary period, and control samples were collected during the week before starting and for a short period following completion of the diet.

Whole stools were collected, weighed, and two samples taken. For bacteriology a sample of $0.5 \mathrm{~g}$ was diluted 1:10 in meat infusion broth (LabLemco, Oxoid Ltd) containing $10 \%$ (v/v) glycerol, carefully emulsified and frozen immediately at $-25^{\circ} \mathrm{C}$. (Crowther, 1971). The other sample (about $20 \mathrm{~g}$ ) was frozen at $-25^{\circ} \mathrm{C}$ undiluted for steroid analysis.

BACTERIOLOGICAL ANALYSIS

The methods used for isolating and counting the bacteria have been described in detail by Drasar and Crowther (1970); the bacterial groups are as described by Drasar (1967) except that the term 'anaerobic lactobacillus' has been replaced by Bifidobacterium spp.

STEROID ANALYSIS

The steroids were extracted, separated into neutral and acid fractions, and further analysed as described by Hill and Aries (1971).

SCREENING OF STRAINS FOR CHOLESTEROL REDUCTASE

The reduction of cholesterol to coprostanol by pure cultures of intestinal bacteria was assayed by growth for seven days in the presence of sub- 
strate in the brain medium described by SnogKjaer, Prange, and Dam (1956). The culture was extracted with chloroform, the extract concentrated by evaporation and analysed by thin-layer chromatography using the method described previously (Hill and Aries, 1971).

The product was isolated by preparative thinlayer chromatography and its identity was confirmed by comparing its melting point $\left(99-100^{\circ} \mathrm{C}\right)$, infra-red, and fluorescence spectra with those of the authentic compound (Koch Light Ltd.) and further confirmed by the mixed melting point $\left(98-100^{\circ} \mathrm{C}\right)$.

\section{Results}

STUDIES IN HEALTHY SUBJECTS

In all three subjects the change from a mixed diet to a liquid diet was accompanied by a marked reduction in the weight of faeces passed; by the end of 10 days on the liquid diet the faecal weight (mean of three days) was reduced from 278 to $85 \mathrm{~g}, 116$ to $54 \mathrm{~g}$, and 107 to $57 \mathrm{~g}$ respectively in the three subjects (table I).

The counts of enterococci fell considerably during the period when the subjects were on the diet (and in one subject they fell below $10^{2}$ per $\mathrm{g}$ which is the lowest level detectable with our techniques), and returned to their former levels on resumption of a normal diet (for example, fig 1). In two persons the counts of 'viridans' streptococci also fell during the course of the diet. An increase in the numbers of enterobacteria was observed. The counts of all other organisms were unchanged by the liquid diet.

The concentration of both acid and neutral

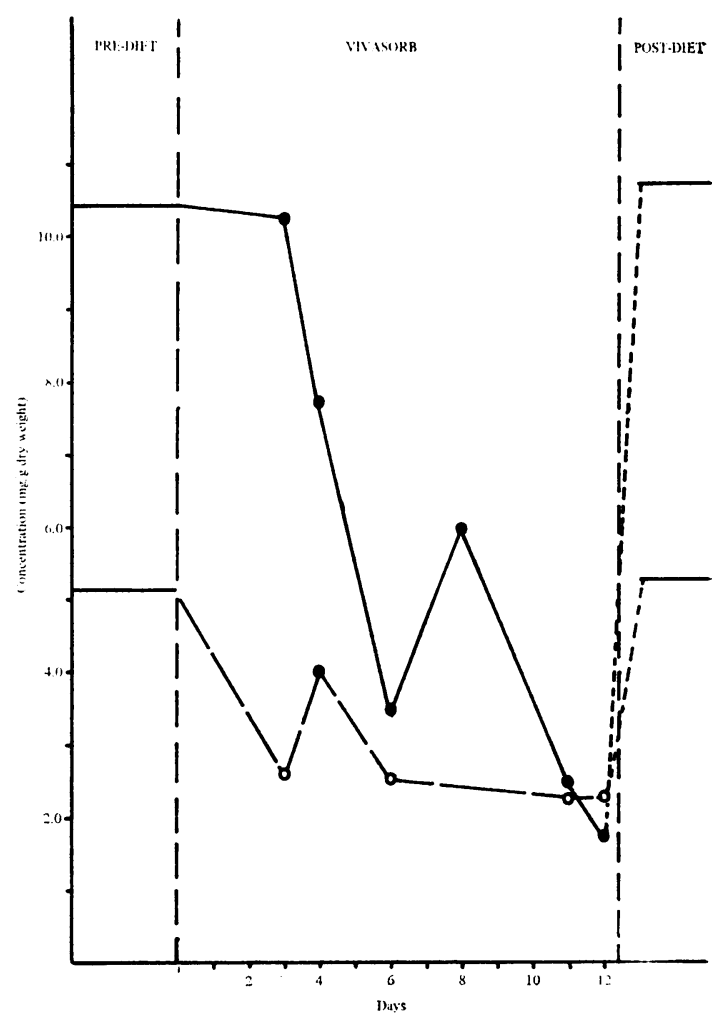

Fig 1 The effect of a liquid diet (Vivasorb) on the faecal concentration of neutral and acid steroids.

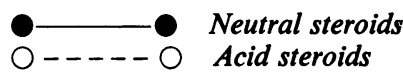

\begin{tabular}{|c|c|c|c|c|c|c|}
\hline \multirow[t]{2}{*}{ Subject } & \multirow[t]{2}{*}{ Time of Assay } & \multirow[t]{2}{*}{$\begin{array}{l}\text { Faecal Mass } 1 \\
(\mathrm{~g} / \text { day })\end{array}$} & \multicolumn{3}{|c|}{$\begin{array}{l}\text { Faecal Steroid Loss per Day } \\
(m g)\end{array}$} & \multirow[t]{2}{*}{ Percentage Degradation of Neutral Steroids } \\
\hline & & & Neutral & Acid & Total & \\
\hline P.R. & $\begin{array}{l}\text { Before diet } \\
\text { End of diet } \\
\text { After diet }\end{array}$ & $\begin{array}{r}278 \\
85 \\
157\end{array}$ & $\begin{array}{r}334 \\
46 \\
203\end{array}$ & $\begin{array}{r}358 \\
47 \\
213\end{array}$ & $\begin{array}{r}692 \\
93 \\
416\end{array}$ & $\begin{array}{r}57 \\
4 \\
53\end{array}$ \\
\hline P.S. & $\begin{array}{l}\text { Before diet } \\
\text { End of diet } \\
\text { After diet }\end{array}$ & $\begin{array}{r}116 \\
54 \\
131\end{array}$ & $\begin{array}{r}334 \\
30 \\
408\end{array}$ & $\begin{array}{r}165 \\
35 \\
205\end{array}$ & $\begin{array}{r}509 \\
65 \\
613\end{array}$ & $\begin{array}{l}57 \\
40 \\
55\end{array}$ \\
\hline R.L. & $\begin{array}{l}\text { Before diet } \\
\text { End of diet } \\
\text { After diet }\end{array}$ & $\begin{array}{r}107 \\
57 \\
82\end{array}$ & $\begin{array}{r}324 \\
30 \\
208\end{array}$ & $\begin{array}{r}194 \\
28 \\
134\end{array}$ & $\begin{array}{r}518 \\
58 \\
342\end{array}$ & $\begin{array}{l}72 \\
10 \\
60\end{array}$ \\
\hline
\end{tabular}

Table I Mean faecal mass and faecal loss of steroids per day during a pre-dietary control period, during the last three days of a 14-day period on a liquid diet, and during a post-dietary control period two weeks after returning to a normal diet

${ }^{1}$ mean of three days. 


\begin{tabular}{|c|c|c|c|}
\hline & Before & Eight to 10 Days & After \\
\hline Enterobacteria & $7.0(5 \cdot 2-8 \cdot 7)$ & $8 \cdot 2(7 \cdot 2-9 \cdot 0)$ & $7 \cdot 2(5.2-8.7)$ \\
\hline Enterococci & $6.9(5.9-8.0)$ & $4.0(1-6.4)$ & $7.6(6.5-8.0)$ \\
\hline Strep. salivarius & $3.0(1-7.7)$ & Not detected & $3.4(1.0-7.9)$ \\
\hline Strep. viridans & $7 \cdot 2(5 \cdot 5-9 \cdot 1)$ & $5 \cdot 3(4 \cdot 5-5 \cdot 5)$ & $8.8(8.0-9.6)$ \\
\hline Bacteroides & $10 \cdot 1(9 \cdot 8-10 \cdot 3)$ & $10.2(9.7-10.8)$ & $10.2(10 \cdot 0-10 \cdot 3)$ \\
\hline Bifidobacteria & $9.7(9 \cdot 5-10 \cdot 2)$ & $9.9(9.4-10.5)$ & $9.8(9 \cdot 2-10 \cdot 3)$ \\
\hline Lactobacilli & $6 \cdot 8(5 \cdot 1-8 \cdot 1)$ & $4 \cdot 3(1-8 \cdot 2)$ & $6.6(4.9-8.0)$ \\
\hline Clostridia & $4.0(2 \cdot 7-7 \cdot 1)$ & $3 \cdot 1(1-5.9)$ & $3.5(2.6-4.0)$ \\
\hline Veillonella & $3.9(1-6.2)$ & $3.0(1-4.6)$ & $5.2(3.0-7.0)$ \\
\hline
\end{tabular}

Table II Faecal flora of three normal subjects before, during, and after a wholely absorbable diet ${ }^{1}$

Two samples from each subject are included in each period.

steroids in the faeces of all three subjects fell during the dietary period (for example, fig 2) to a mean value of 2.0 and $1.9 \mathrm{mg} / \mathrm{g}$ dry weight respectively, and was accompanied by a decrease in the degree of degradation of the neutral steroids. During the control period, $55-75 \%$ of the total neutral steroids were in the form of the bacterial metabolites coprostanol and coprostanone but by the end of the period on a liquid diet these metabolites accounted for only 4 to $10 \%$ of the total in two of the subjects and for $40 \%$ in the remaining one.

The percentage of neutral steroids in the form of cholesterol metabolites correlated well with the number of enterococci per gram faeces (fig 3 ).

\section{REDUCTION OF CHOLESTEROL TO}

\section{COPROSTANOL BY PURE BACTERIAL}

CULTURES

Twenty strains each of the aerobic organisms Escherichia coli and Streptococcus faecalis and of the anaerobic spore-forming bacteria Clostridium spp together with 18 and 12 respectively of the strictly anaerobic non-spore-forming Bacteroides spp and Bifidobacterium spp were tested for their ability to reduce cholesterol to coprostanol (fig 5). This is quantitatively the most important metabolic

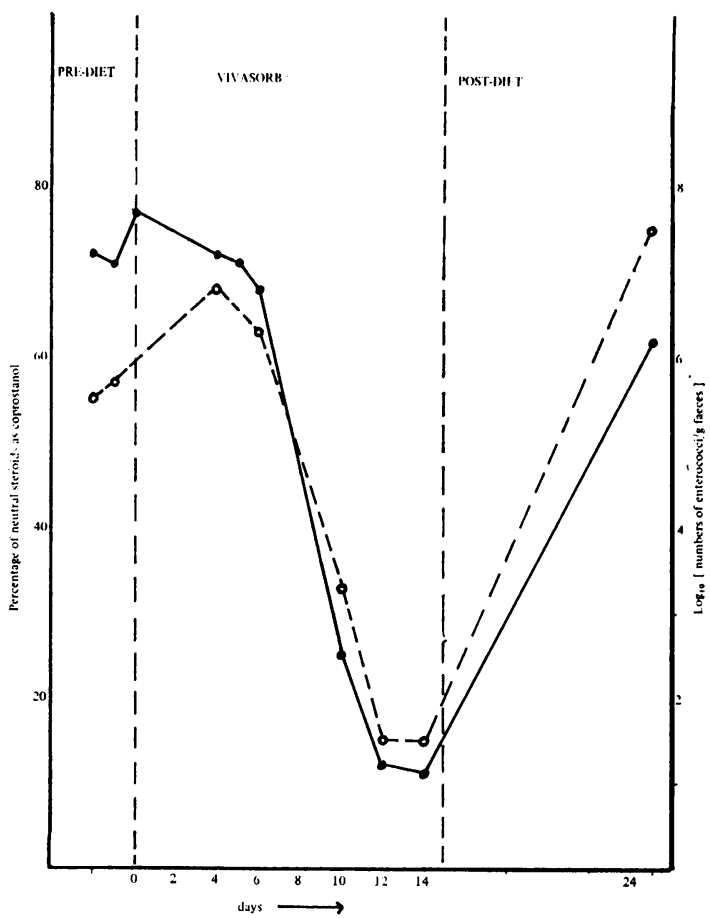

Fig 2 The effect of a liquid diet (Vivasorb) on the bacterial reduction of cholesterol and on the numbers of enterococci

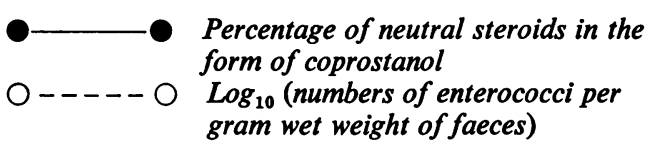

reaction carried out by gut bacteria on the faecal steroids. None of the aerobic organisms performed this nuclear hydrogenation but a high proportion of strains of the three anaerobic genera produced coprostanol (table III).

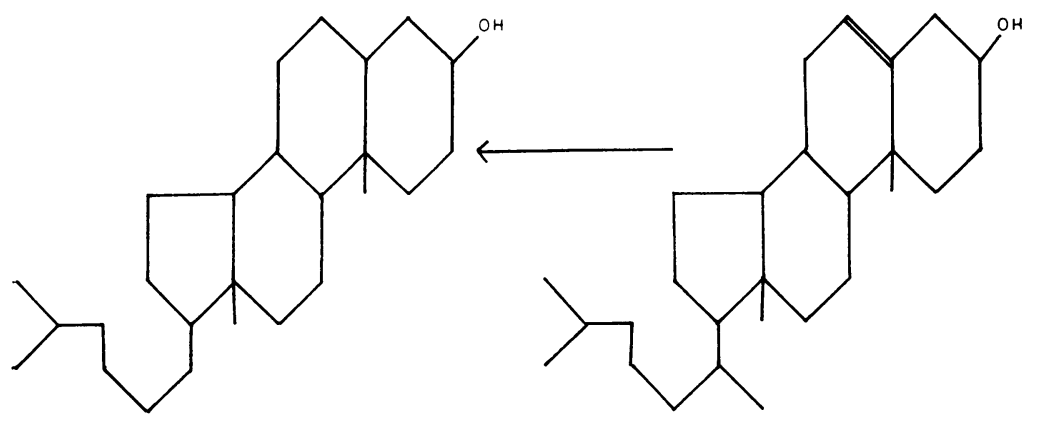

Fig 3 Bacterial reduction of cholesterol to coprostanol 


\begin{tabular}{llc}
\hline & No. Strains Tested & $\begin{array}{l}\text { No. Strains Able } \\
\text { to Reduce } \\
\text { Cholesterol }\end{array}$ \\
\hline Esch. coli & 20 & 0 \\
Str. faecalis & 20 & 0 \\
Clostridium spp & 20 & $9^{1}$ \\
Bacteroides spp & 18 & 12 \\
Bifidobacterium spp & 12 & 9 \\
\hline
\end{tabular}

Table III Ability of intestinal strains of bacteria to reduce cholesterol to coprostanol

${ }^{1}$ Clostridia only converted $15-20 \%$ of cholesterol to coprostanol compared with more than $50 \%$ for some Bacteroides strains.

\section{Discussion}

The observation that the neutral steroids of people living on the liquid diet were virtually unmetabolized by the gut bacteria is of great interest, especially in view of the remarkably long transit time in these people. Obviously, of the many factors determining the degree of degradation of faecal steroids the time for which the substrate is exposed to the bacteria is of relatively minor importance. The lack of metabolism may reflect some subtle change in the bacterial species present in the gut, with an organism normally present and able to reduce cholesterol being replaced by an inactive species of the same genus. Alternatively the paucity of nutrients in the colon might result in a reduction in the synthesis of degradative enzymes which are ecologically inessential. The possibility that cholesterol levels might be too low to stimulate enzyme production can probably be discounted as we have no evidence that these enzymes are inducible. Although the disappearance of enterococci correlates well with the decrease in cholesterol metabolism, they were inactive in studies in vitro, indicating that this correlation is probably fortuitous.

The concentration of faecal acid and neutral steroid fell rapidly when volunteers lived on a low-fat liquid diet, and this result was expected by analogy with the results obtained with volunteers living on a low-fat solid diet (Hill, 1971).

The daily faecal bile acid excretion rate of 30 to 40 $\mathrm{mg} /$ day was about half that of people living on the low-fat solid diet; thus in an acute experiment of two weeks the daily faecal bile acid excretion can be reduced by 150 to $200 \mathrm{mg}$, to about 25 to $30 \%$ of its normal value by drastically reducing the amount of dietary fat and can be reduced by a further 30 to $\mathbf{4 0} \mathrm{mg}$ by reducing to zero the amount of indigestible solids. It is known that by increasing the amount of dietary fibre of some diets the daily faecal bile acid loss can be increased (Antonis and Bersohn, 1962) and we are currently investigating this further.

The liqud diet had no profound effect on the overall flora of the faeces since the total number of organisms per gram of faeces remained at the control value of $10^{10}-10^{11}$. However, there was an effect on the streptococci, with the enterococci being reduced in numbers in all three subjects and the 'viridans' streptococci being reduced in two of the three. In a similar study by Attebery, Sutter, and Finegold (1972) the numbers of enterococci were reduced in two of the three subjects. In both the current study and that of Finegold an increase in the numbers of enterobacteria was observed.

We would like to acknowledge the technical assistance of Miss Fresia Fernandez, and the financial support of the Cancer Research Campaign and Wellcome Trust.

\section{References}

Antonis, A., and Bersohn I. (1962). The influence of diet on fecal lipids in South African white and Bantu prisoners. Amer. $J$. clin. Nutr., 11, 142-155.

Aries, V. C., Crowther, J. S., Drasar, B. S., Hill, M. J., and Ellis, F. R. (1971). The effect of a strict vegetarian diet on the faecal flora and faecal steroid concentration. J. Path., 103, 54-56.

Attebery, H. R., Sutter, V. L., and Finegold, S. M. (1972). Effect of a partially chemically defined diet on normal human fecal flora. Amer. J. clin. Nutr., 25, 1391-1398.

Crowther, J. S. (1971). Transport and storage of faeces for bacteriological examination. J. appl. Bact., 34, 477-483.

Drasar, B. S. (1967). Cultivation of anaerobic intestinal bacteria. J. Path. Bact., 94, 417-427.

Drasar, B. S. and Crowther, J. S. (1970). Soc. Appl. Bact. Techn. Series, No. 5.

Hill, M. J. (1971). The effect of some factors on the feacal concentration of steroids, neutral steroids, and urobilins. J. Path., 104, 239-245.

Hill, M. J., and Aries, V. C. (1971). Faecal steroid composition and its relationship to cancer of the large bowel. J. Path., 104, 129139.

Hill, M. J., Crowther, J. S. Drasar, B. S. Hawksworth, G. M., Aries, V. C., and Williams, R. E. O. (1971a). Bacteriology and aetiology of cancer of the large bowel. Lancet, 1, 95-103.

Hill, M. J., Goddard, P., and Williams, R. E. O. (1971b). Gut bacteria and aetiology of cancer of the breast. Lancet, 2 , 472-473.

Snog-Kjaer, A., Prange, I., and Dam, H. (1956). Conversion of cholesterol into coprosterol by bacteria in vitro. J. gen. Microbiol., $14,256-260$

Winitz, M., Graff, J., Gallagher, N., Narkin, A., and Seedman, D. A. (1965). Evaluation of chemical diets as nutrition for man-inspace. Nature (Lond.), 205, 741-743. 